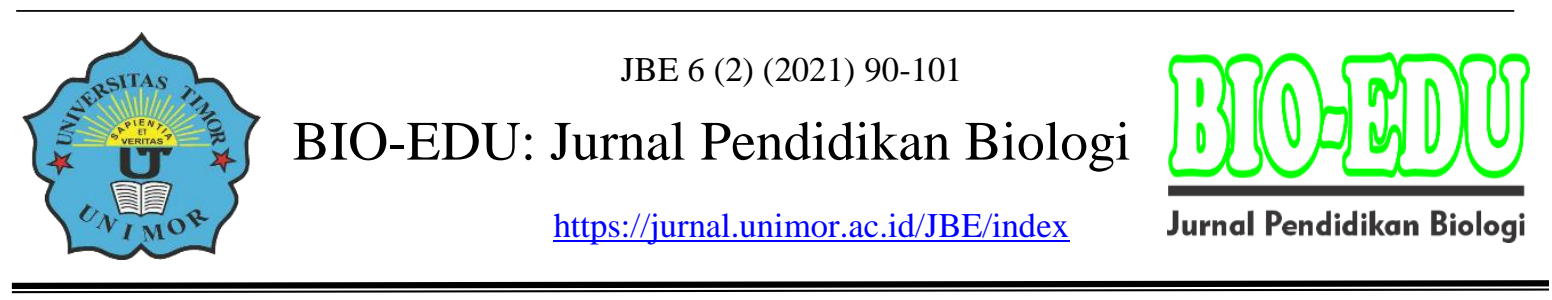

\title{
Keanekaragaman Jenis Kupu-Kupu (Rhopalocera: Papilionoidea dan Hesperioidea) di Kawasan Cagar Alam Gunung Sigogor Kecamatan Ngebel, Kabupaten Ponorogo
}

\author{
Siti Zulaikha1, Saiful Bahri \\ ${ }^{1}$ Biologi, Universitas Islam Negeri Sunan Ampel Surabaya, Jl. Ahmad Yani No. \\ 117, Jemur Wonosari, Kecamatan Wonocolo, Surabaya 60237 Jawa Timur \\ ${ }^{2}$ Biologi, Universitas Islam Negeri Sunan Ampel Surabaya, Jl. Ahmad Yani No. \\ 117, Jemur Wonosari, Kecamatan Wonocolo, Surabaya 60237 Jawa Timur \\ Email: zulaikasiti456@gmail.com
}

\section{DOI: https://doi.org./10.32938/jbe.v6i2.1189}

\begin{abstract}
Abstrak
Penelitian mengenai keanekaragaman jenis kupu-kupu memang telah banyak dilakukan di Indonesia terutama di wilayah Jawa Timur, namun belum mancangkupi seluruh daerah khususnya pada kawasan Cagar Alam Gunung Sigogor, Kecamatan Ngebel, Kabupaten Ponorogo yang merupakan kawasan konservasi. Penelitian dilakukan bertujuan untuk mengidentifikasi dan mengetahui keanekaragaman jenis kupu-kupu. Pemilihan lokasi penelitian disesuaikan dengan perbedaan komposisi vegetasi, habitat, posisi aliran air dan kemudahan akses. Metode yang digunakan dalam penelitian yaitu Visual Encounter Survey dan dianalisis menggunakan Indeks Shannon-Wiener. Jumlah spesies yang didapat sebanyak 45 spesies dari 5 famili 321 individu dengan nilai $\mathrm{H}^{\prime}=2.42$ sehingga dapat mendeskripsikan kualitas lingkungan pada kawasan Cagar Alam Gunung Sigogor.
\end{abstract}

Kata Kunci: "Kupu-kupu”, "Keanekaragaman Jenis”, “Indeks Shannon-Wiener”, "Faktor Lingkungan”

\begin{abstract}
Research on the diversity of butterfly species has been conducted in Indonesia, especially in East Java, but has not covered the entire region, especially in the area Cagar Alam Gunung Sigogor, Ngebel District, Ponorogo Regency which is a conservation area. The presence of butterflies in nature can be a benchmark and domiciled as pollinator insects to maintain biodiversity in the region. The selection of research sites is adjusted to the composition of vegetation, habitat differences, water flow position and ease of access. The method used in the study was the Visual Encounter Survey and was analyzed using the Shannon-Wiener Index. The number of species obtained as many as 45 species from 5 families of 321 individuals with a value of $\mathrm{H}^{\prime}=2.42$ so as to describe the quality of the environment at the Cagar Alam Gunung Sigogor.
\end{abstract}

Keywords: "Butterflies", "Diversity of Species", "Shannon-Wienner Index", "Environmemtal factors"

\section{PENDAHULUAN}

Cagar Alam Gunung Sigogor merupakan kawasan konservasi di Kabupaten Ponororgo, yang dikelola langsung oleh Balai Besar Konservasi dan Sumber Daya Lingkungan Hidup Jawa Timur dengan luas 190,5 Ha. Kawasan cagar alam dapat berpotensi sebagai habitat asli bagi berbagai keanekaragaman makhluk hidup. Keanekaragaman diartikan semua jenis makhluk hidup yang berada pada suatu kawasan dan ikut andil dalam mempertahankan ekosistem (Safe'i dkk., 2018). 
Kupu-kupu adalah serangga berukuran sedang dengan bentuk tubuh dan ragam corak yang unik. Struktur tubuh kupu-kupu terdiri dari kepala, thoraks, dan abdomen. Memiliki antena tipis dengan ujung yang membulat dan warna sayap yang cerah (Peggie, 2014). Selain itu kupu-kupu memiliki mata majemuk, mulut tipe penghisap yang disebut probocis (Baskoro dkk., 2018). Sepasang sayap kupu-kupu mengandung sisik cerah sehingga memiliki kesan bercorak dan mengandung nilai artistik (Farzana \& Anzela, 2016). Oleh karena itu secara taksonomi kupu-kupu dikelompokkan dalam Lepidoptera sub ordo Rhopalocera.

Kupu-kupu mengalami metamorfosis sempurna yang terdiri dari Telur, Larva, Pupa dan Imago. Tingkat keberhasilan kupu-kupu dalam beradaptasi terhadap lingkungannya sangat dipengaruhi oleh faktor biotik berupa tanaman pakan dan inang (Ashari dkk., 2019). Oleh karena itu kupu-kupu memiliki fungsi ekologi mempertahankan keseimbangan ekosistem dan meperkaya keanekaragaman hayati (Setiawan dkk., 2018), sehingga keberadaan kupu-kupu dapat dijadikan sebagai tolak ukur kualitas lingkungan.

Pulau Jawa merupakan salah satu pulau yang terus mengalami deforestasi setiap tahunnya, hal ini dapat menekan mengancam populasi kupu-kupu (Ahmed \& Farid, 2014) khususnya di jawa timur. Kawasan Cagar Alam yang sulit dijangkau oleh masyarakat menjadikan kondisi lingkungannya masih terjaga alami serta dapat meminimalisir adanya deforestasi dan alih fungsi lahan (Peggie, 2014). Keanekaragaman jenis kupu-kupu dapat berbeda antara satu daerah dengan daerah lainnya, hal ini dikarenakan setiap daerah memiliki perbedaan habitat, komposisi vegetasi, tipe kanopi dan faktor biotik dan lingkungan. Belum adanya data mengenai keanekaragaman jenis kupu-kupu di kawasan Cagar Alam Gunung Sigogor menjadi tujuan dalam penelitian dengan cara mengidentifikasi dan menganalisis keanekaragaman kupu-kupu di kawasan Cagar Alam Gunung Sigogor.

\section{METODE}

Alat yang digunakan dalam penelitian ini meliputi: GPS (Global Positioning System), Jam Tangan, Insect net, Kamera, Termohigrometer dan Alat Tulis. Data yang diperoleh dalam pengamatan diidentifikasi lebih lanjut menggunakan buku identifikasi (Mustari \& Gunadharma, 2016; Baskoro dkk., 2018 \& Rohman dkk., 2019)

Penelitian dilakukan pada bulan Januari-Februari 2021 di kawasan Cagar Alam Gunung Sigogor Kabupaten Ponorogo Jawa Timur dengan letak geografi kawasan $07^{\circ}$

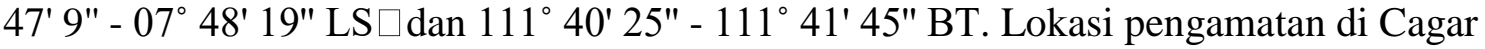
Alam Gunung Sigogor dibagi menjadi lima stasiun pengamatan yang didasari oleh perbedaan komposisi vegetasi, habitat, posisi aliran air dan kemudahan akses. Pengambilan data dilakukan dengan metode Visual Encounter Survey (VES) (Lestari et al., 2018). Visual Encounter Survey merupakan metode yang dilakukan dengan mencatat spesies dan menghitung jumlah individu dengan 2 kali pengulangan pada jam aktif kupukupu (08.00 - 13.00 WIB). Kemudian data yang diperoleh dianalisis menggunakan Indeks Keanekaragaman jenis Shannon-Wienner (Magurran, 1988). Berikut formula dari analisis:

Indeks Shannon-Wiener

Keterangan:

$$
\mathrm{H}^{\prime}=-\sum p_{i} \operatorname{In} p_{i}
$$

$$
\begin{array}{ll}
\mathrm{H}^{\prime} & =\text { Indeks Keanekaragaman Jenis Shannon-Wiener } \\
p_{i} & =\text { Rasio } n_{i} / N
\end{array}
$$




$$
\begin{array}{ll}
n_{i} & =\text { Jumlah individu spesies } \mathrm{i} \\
\mathrm{N} & =\text { Jumlah total individu }
\end{array}
$$

Menurut Krebs (1989) nilai indeks keanekaragaman dapat diklasifikasikan dalam beberapa kategori yaitu:
$\mathrm{H}^{\prime}<1$
: Keanekaragaman spesies rendah
$H^{\prime}=1-3 \quad$ : Keanekaragaman spesies sedang
H’>1 : Keanekaragaman spesies tinggi

\section{HASIL DAN PEMBAHASAN}

Hasil analisis data dapat menunjukkana bahwa keanekaragaman kupu-kupu pada kawasan Cagar Alam Gunung Sigogor Kabupaten Ponorogo terdapat sebanyak 45 spesies dari 5 Famili dengan 321 jumlah individu. Jenis kupu-kupu yang dilindungi menurut IUCN, CITES (Apendix), dan P.20/2018 sebagai berikut:

Tabel 1. Keanekaragaman Jenis Kupu-kupu di kawasan Cagar Alam Gunung Sigogor

\begin{tabular}{|c|c|c|c|c|c|c|c|c|c|c|}
\hline \multirow[b]{2}{*}{ Famili } & \multirow[b]{2}{*}{ Spesies } & \multicolumn{5}{|c|}{ Lokasi } & \multirow{2}{*}{$\begin{array}{c}\text { Jumlah } \\
\text { Total }\end{array}$} & \multicolumn{3}{|c|}{ Status Konservasi } \\
\hline & & L1 & $\mathbf{L 2}$ & $\mathbf{L 3}$ & L4 & L5 & & IUCN & $\begin{array}{c}\text { CITES } \\
\text { (Apendix) }\end{array}$ & $\begin{array}{l}\text { P.20/ } \\
2018\end{array}$ \\
\hline \multirow[t]{6}{*}{ 1. Papilionidae } & 1. Papilio memnon & 2 & 8 & 4 & 1 & 9 & 24 & NA & - & - \\
\hline & 2. Troides helena & - & 1 & 2 & 2 & 3 & 8 & $\mathrm{LC}$ & II & $\sqrt{ }$ \\
\hline & $\begin{array}{l}\text { 3. Troides } \\
\text { amphrysus }\end{array}$ & - & - & 1 & 3 & 2 & 6 & $\mathrm{LC}$ & II & $\sqrt{ }$ \\
\hline & 4. Graphium doson & - & 1 & 1 & - & 3 & 5 & NA & - & - \\
\hline & $\begin{array}{l}\text { 5. Graphium } \\
\text { agamemnon }\end{array}$ & - & - & - & - & 2 & 2 & NA & - & - \\
\hline & $\begin{array}{l}\text { 6. Graphium } \\
\text { sarpedon }\end{array}$ & - & - & - & - & 2 & 2 & NA & - & - \\
\hline \multirow[t]{7}{*}{ 2. Nymphalidae } & 7. Ypthima baldus & 28 & 11 & 17 & - & 12 & 68 & NA & - & - \\
\hline & $\begin{array}{l}\text { 8. Ypthima } \\
\text { pandocus }\end{array}$ & - & - & - & 5 & - & 5 & NA & - & - \\
\hline & $\begin{array}{l}\text { 9. Mycalesis } \\
\text { horsfieldi }\end{array}$ & 6 & 4 & - & - & - & 10 & NA & - & - \\
\hline & $\begin{array}{l}\text { 10. Mycalesis } \\
\text { janardana }\end{array}$ & 2 & - & - & - & 1 & 3 & $\mathrm{LC}$ & - & - \\
\hline & $\begin{array}{l}\text { 11. Mycalesis } \\
\text { moorei }\end{array}$ & - & - & - & 3 & 5 & 8 & NA & - & - \\
\hline & 12. Neptis hylas & - & 1 & 1 & - & 2 & 4 & NA & - & - \\
\hline & $\begin{array}{l}\text { 13. Parantica } \\
\text { aspasia }\end{array}$ & - & 1 & - & - & - & 1 & NA & - & - \\
\hline
\end{tabular}
dan Status Konservasi menurut IUCN, CITES (Apendix), dan P.20/2018 


\begin{tabular}{|c|c|c|c|c|c|c|c|c|c|c|}
\hline & $\begin{array}{l}\text { 14. Symbrenthia } \\
\text { lilea }\end{array}$ & - & 3 & - & - & - & 3 & NA & - & - \\
\hline & $\begin{array}{l}\text { 15. Symbrenthia } \\
\text { hypselis }\end{array}$ & - & - & 3 & - & - & 3 & NA & - & - \\
\hline & 16. Lethe confusa & - & 2 & 1 & - & - & 3 & NA & - & - \\
\hline & 17. Junonia iphita & - & 1 & - & - & 6 & 7 & NA & - & - \\
\hline & $\begin{array}{l}\text { 18. Junonia } \\
\text { hedonia }\end{array}$ & 1 & - & - & - & - & 1 & NA & - & - \\
\hline & 19. Euploea sp. & - & - & - & 1 & - & 1 & NA & - & - \\
\hline & 20. Melanithis leda & 1 & - & - & - & 3 & 4 & NA & - & - \\
\hline & $\begin{array}{l}\text { 21. Amathusia } \\
\text { phidippus }\end{array}$ & 1 & - & - & - & - & 1 & NA & - & - \\
\hline & $\begin{array}{l}\text { 22. Lethe } \\
\text { manthara }\end{array}$ & - & - & - & - & 5 & 5 & NA & - & - \\
\hline & 23. Euploea core & - & - & - & - & 2 & 2 & $\mathrm{LC}$ & - & - \\
\hline & 24. Cyrestis lutea & - & 1 & - & - & - & 1 & NA & - & - \\
\hline & 25. Cyrestis rahria & - & - & - & - & 2 & 2 & NA & - & - \\
\hline & 26. Vagrans egista & - & - & - & 5 & - & 5 & NA & - & - \\
\hline & 27. Tanaecia iapis & - & - & 2 & - & - & 2 & NA & - & - \\
\hline 3. Pieridae & 28. Eurema hecabe & 13 & 6 & 3 & - & - & 22 & NA & - & - \\
\hline & 29. Eurema blanda & 1 & 2 & 3 & 3 & 10 & 19 & NA & - & - \\
\hline & 30. Eurema sari & 1 & - & - & - & 4 & 5 & NA & - & - \\
\hline & 31. Cephora iudith & - & 1 & - & - & - & 1 & NA & - & - \\
\hline & $\begin{array}{l}\text { 32. Delias } \\
\text { belisama }\end{array}$ & - & - & 1 & - & 6 & 7 & NA & - & - \\
\hline & $\begin{array}{l}\text { 33. Catopsilia } \\
\text { pomona }\end{array}$ & - & 2 & - & - & - & 2 & NA & - & - \\
\hline & 34. Letopsia nina & - & - & - & - & 1 & - & NA & - & - \\
\hline 4. Lycaenidae & $\begin{array}{l}\text { 35. Pithecops } \\
\text { corvus }\end{array}$ & - & - & 4 & - & 1 & 5 & NA & - & - \\
\hline & $\begin{array}{l}\text { 36. Heliophorus } \\
\text { epicles }\end{array}$ & 3 & 3 & 3 & - & 3 & 12 & NA & - & - \\
\hline & $\begin{array}{l}\text { 37. Taraka } \\
\text { hamada }\end{array}$ & 1 & - & - & - & - & 1 & NA & - & - \\
\hline & 38. Udara akasa & - & - & 1 & - & 4 & 5 & NA & - & - \\
\hline & 39. Jamides sp. & - & - & - & - & 7 & 7 & NA & - & - \\
\hline 5. Hespiriidae & $\begin{array}{l}\text { 40. Notocripta } \\
\text { curvifascia }\end{array}$ & 3 & 2 & 1 & 1 & 3 & 10 & NA & - & - \\
\hline
\end{tabular}




\begin{tabular}{|c|c|c|c|c|c|c|c|c|c|}
\hline $\begin{array}{l}\text { 41. Pseudocaladen } \\
\text { ia dan }\end{array}$ & 2 & 1 & - & 1 & - & 4 & NA & - & - \\
\hline $\begin{array}{l}\text { 42. Potanthus } \\
\text { omaha }\end{array}$ & 2 & 7 & - & - & - & 9 & NA & - & - \\
\hline $\begin{array}{l}\text { 43. Charmion } \\
\text { ladana }\end{array}$ & 11 & - & - & - & - & 11 & NA & - & - \\
\hline $\begin{array}{l}\text { 44. Calaenorrhinu } \\
\text { s asmara }\end{array}$ & - & - & - & - & 3 & 3 & NA & - & - \\
\hline 45. Borbo cinnara & - & - & - & - & 2 & 2 & NA & - & - \\
\hline
\end{tabular}

L1: Lokasi 1, L2: Lokasi 2, L3: L4: Lokasi 4, L5: Lokasi 5, LC : Least concern, NA: Not available, dan II: Apendix 2

Berdasarkan (Tabel 1) diketahui bahwa terdapat 3 spesies yang ditemukan pada setiap lokasi yaitu Papilio memnon, Eurema blanda dan Notocripta paralysos. Ketiga spesies tersebut dapat ditemukan di berbagai tipe habitat dengan kondisi kanopi terbuka ataupun tertutup. Menurut (N N Win, 2005), Papilio memnon merupakan spesies yang memiliki tingkat adaptasi tinggi terhadap perubahan musim sehingga disebut sebagai spesies yang dapat ditemukan dalam jangka waktu panjang. Papilio memnon termasuk kedalam famili Papilionidae yang dikenal dengan kupu-kupu penerbang kuat karena memiliki tubuh yang besar, bersayap lebar berkisar 5-28 cm (Rohman dkk., 2019 dengan warna dasar hitam dan terdapat bercak kuning atau merah di basal sayap (Baskoro dkk., 2018).

Eurema blanda menurut (Payra, 2020) merupakan spesies yang dapat ditemukan di berbagai kondisi lingkungan dengan intensitas cahaya matahari yang sedang sampai rendah karena memiliki sifat mudah untuk beradaptasi dengan lingkungannya. Eurema blanda termasuk kedalam famili Pieridae yang umumnya dikenal sebagai spesies penerbang jarak pendek, ukuran tubuh kecil sampai sedang, memiliki lebar sayap 22-35 mm (Rohman dkk., 2019) dengan warna dasar kuning dan terdapat bercak hitam pada marginal sayap (Borror dkk., 2005).

Notocrypta curvifascia adalah spesies yang dapat ditemukan di berbagai tipe kondisi lingkungan di kawasan Cagar Alam Gunung Sigogor karena memiliki tingkat adaptasi yang baik dalam intensitas cahaya rendah sampai tinggi. Notocrypta curvifascia memiliki sayap berwarna coklat kehitaman dengan pita putih pada medial sayap atas depan dan belakang, (Baskoro et al., 2018) menambahkan bahwa Notocrypta curvifascia memiliki ujung antena berwarna jingga, tungkai coklat gelap, dan terdapat tiga titik putih pada subapikal sayap depan. Spesies ini tergolong dalam kelompok famili Hespiridae dengan kemampuan terbang yang cepat, jarak terbang dekat, bersayap pendek, umumnya memiliki sayap berwarna dasar hitam dengan bercak putih atau kuning, dan berukuran tubuh sedang (Borror dkk., 2005).

Berdasarkan hasil analisis jumlah dan keanekaragaman jenis Indeks ShanonWiener pada setiap lokasi pengamatan dapat dilihat pada tabel 2 sebagai berikut: 
Tabel 2. Indeks Keanekaragaman jenis kupu-kupu

\begin{tabular}{ccccccc}
\hline \multirow{2}{*}{ Indeks } & \multicolumn{5}{c}{ Lokasi } & Total \\
\cline { 2 - 6 } & L1 & L2 & L3 & L4 & L5 & \\
\hline $\mathbf{S}$ & 17 & 18 & 16 & 11 & 27 & 89 \\
\hline $\mathbf{N}$ & 79 & 56 & 48 & 26 & 105 & 314 \\
\hline H' & 2.1 & 2.5 & 2.3 & 2.2 & 3.0 & 3.1
\end{tabular}

S: Jumlah jenis, N: Jumlah individu, L1: Lokasi 1, L2: Lokasi 2, L3: L4: Lokasi 4, L5: Lokasi 5 dan H': Indeks Keanekaragaman Jenis Shanon Wiener

Jumlah jenis dan jumlah individu yang dijumpai di kawasan Cagar Alam Gunung Sigogor sebanyak 89 jenis dengan 321 jumlah individu. Hal ini menunjukkan bahwa kawasan Cagar Alam Gunung Sigogor cukup baik untuk mendukung keberlangsungan hidup berbagai jenis kupu-kupu. Nilai jumlah jenis dan individu kupu-kupu di kawasan Cagar Alam Gunung Sigogor lebih rendah dari jumlah jenis dan individu kupu-kupu di Gunung Sago dengan 182 spesies dengan 3056 individu (Rusman dkk., 2015). Namun jumlah jenis dan individu kupu-kupu di Cagar Alam Gunung Sigogor lebih tinggi dari kawasan Deudap Pulo Aceh dengan 22 jenis dan 109 individu (Rahman dkk., 2018).

Hasil analisis jumlah jenis dan jumlah individu pada setiap lokasi memiliki jumlah jenis dan jumlah individu yang berbeda. Hal ini dikarenakan setiap lokasi memiliki karakteristik tipe habitat, vegetasi dan tutupan kanopi yang berbeda-beda, sehingga hanya spesies kupu-kupu tertentu yang ditemukan di setiap lokasi. Pernyataan ini didukung oleh (Setiawan dkk., 2018) yang menyatakan bahwa spesies kupu-kupu pada suatu tempat akan berbeda jenisnya dengan tempat lain. Berdasarkan (Tabel 2) diatas diketahui bahwa lokasi keempat memiliki jumlah jenis dan individu yang terendah. Lokasi keempat merupakan habitat dengan lingkungan tertutup, sedikit vegetasi dan letak topografi yang paling tinggi jika dibandingkan dengan lokasi satu, dua, tiga dan lima. Lokasi ini memiliki aliran air kecil sehingga vegetasi yang tumbuh tidak beragam dan hal ini berbanding lurus dengan keanekaragaman jenis kupukupu (Sari dkk., 2017). Ketinggian lokasi dan kerapatan kanopi dapat berpengaruh terhadap struktur komunitas di suatu lokasi, sehingga berdampak pada keberadaan jenis kupu-kupu.

Berdasarkan analisis yang telah dilakukan total nilai indeks Shannon-Wiener pada kawasan Cagar Alam Gunung Sigogor yakni H'=3.1. Hasil dari nilai tersebut diketahui bahwa indeks Shannon-Wiener kupu-kupu di kawasan Cagar Alam Gunung Sigogor dalam kategori tinggi. Menurut Nino (2019) menyatakan bahwa jika nilai indeks >3, maka kawasan tersebut memiliki keanekaragaman jenis yang tinggi. Hal ini menunjukkan bahwa kondisi lingkungan pada kawasan Cagar Alam Gunung Sigogor sangat baik untuk keberlangsungan hidup kupu-kupu. Nilai indeks keanekaragaman kupu-kupu di kawasan Cagar Alam Gunung Sigogor lebih tinggi dari pada nilai indeks keanekaragaman pada kawasan Hutan Pendidikan Gunung Walat Sukabumi, Jawa Barat dengan nilai H' $=2.16$ (Bahar dkk., 2016). Namun nilai indeks keanekaragaman kupu-kupu di kawasan Cagar Alam Gunung Sigogor lebih rendah dari pada nilai indeks keanekaragaman kupu-kupu di kawasan Taman Kehati Unnes dengan H' = 3.72 (Priyono dan Abdullah, 2013).

Berdasarkan (Tabel 2) diatas dapat diketahui bahwa setiap lokasi memiliki nilai indeks keanekaragaman yang berbeda-beda. Lokasi kelima memiliki nilai indeks 
keanekaragaman tertinggi $H^{\prime}=3$. Sedangkan nilai indeks keanekaragaman terendah yaitu lokasi pertama $\mathrm{H}^{\prime}=2.1$ dimana sebagian besar spesies kupu-kupu yang ditemukan pada lokasi kelima tidak ditemukan di lokasi pertama, kedua, ketiga dan keempat.

Lokasi kelima merupakan habitat dengan kondisi lingkungan terbuka, terdapat banyak tanaman herba, serta kanopi pada beberapa titik. Tutupan kanopi yang tidak terlalu banyak menyebabkan cahaya masuk ke lingkungan sehingga suhu menjadi hangat dan kelembaban menurun. Kupu-kupu merupakan serangga poikilotermik yang membutuhkan suhu optimum agar sistem metabolisme dalam tubuh dapat berjalan dengan baik (Mukarromah et al., 2019). Oleh karena itu pada lokasi kelima memiliki nilai keanekaragaman tertinggi dan disebabkan banyak dijumpai sekelompok kupu-kupu yang berjemur di bawah matahari dan melakukan nektaring pada tanaman pakannya. Tanaman yang dimanfaatkan sebagai tempat beristirahat dan sumber pakan yaitu Eupatorium inulifolium, Mimosa caesalpiniaefolia, Mimosa pudica, Coffea sp., Bambusa sp., Tamarindus indica, Ageratum conyzoides, Chromolaena odorata, Tristaniopsisi laurina, Mimulus alatus, Alliaria petiolata, Ageratina riparia, Japanse stiltgrass, Dichanthelium clandestinum, Rubus rosifolius, Bidens pilosa dan Eupatorium perfoliatum.

Lokasi pertama memiliki kondisi habitat dan lingkungan tertutup, terdapat banyak tanaman herba, kerapatan kanopi dan letaknya yang dekat dengan perkebunan warga. Tutupan kanopi yang mendominan menyebabkan cahaya tidak dapat masuk ke lingkungan sehingga suhu menurun dan kelembaban menjadi tinggi. Beberapa spesies yang ditemukan pada lokasi pertama adalah jenis dengan tingkat toleransi tinggi terhadap lingkungan. Suhu lingkungan berkisar pada angka $20-35^{\circ} \mathrm{C}$, kelembaban $64-94 \%$ dan intensitas cahaya 2.000-7.500 1x. Menurut Ilhamdi et al. (2018) jika kelembaban lingkungan melebihi 95\% maka kupu-kupu akan sangat sulit dijumpai pada suatu lokasi. Pernyataan tersebut juga diperkuat oleh (Ashari et al., 2019 \& Chahyadi et al., 2020) tinggi rendahnya suhu dan kelembaban lingkungan serta intensitas cahaya dapat memengaruhi aktivitas hidup kupu-kupu. Berikut merupakan tabel faktor lingkungan pada kawasan Cagar Alam Gunung Sigogor:

Tabel 3. Faktor Lingkungan

\begin{tabular}{ccc}
\hline No & Faktor Lingkungan & Nilai \\
\hline $\mathbf{1}$ & Suhu $\left({ }^{\circ} \mathrm{C}\right)$ & $22,4-28,3$ \\
$\mathbf{2}$ & Kelembaban $(\%)$ & $71,7-87,3$ \\
$\mathbf{3}$ & Intensitas Cahaya (lx) & $2479-24277$ \\
\hline
\end{tabular}

Jenis yang paling banyak pada kawasan Cagar Alam Gunung Sigogor berasal dari famili Nymphalidae sebanyak 21 spesies. Tingginya jumlah spesies dari famili Nymphalidae ini menurut Borror dkk. (2005) karena merupakan salah satu famili dengan jumlah yang besar dalam sub Ordo Rhopalocera sehingga mudah dijumpai di alam. Menurut Mogan dkk. (2018) menyatakan bahwa Nymphalidae merupakan famili dengan memiliki tingkat adaptasi yang sangat baik terhadap perubahan lingkungan. Rahayuningsih dkk. (2012) menambahkan spesies dari famili Nymphalidae disebut sebagai kelompok kupu-kupu polyfag karena memiliki lebih dari satu jenis tanaman pakan, ketersediaan tanaman pakan yang melimpah menjadikan spesies dari famili Nymphalidae sangat banyak jumlahnya di alam karena didukung oleh berbagai faktor. 
Salah satu spesies dari famili Nympahlidae yang paling banyak dijumpai di kawasan Cagar Alam Gunung Sigogor ialah Ypthima baldus sebanyak 68 individu. Jumlah tersebut menunjukkan bahwa Ypthima baldus merupakan spesies yang mendominasi dan mudah dijumpai di lokasi pengamatan kawasan Cagar Alam Gunung Sigogor. Berikut merupakan hasil dokumentasi dari Ypthima baldus

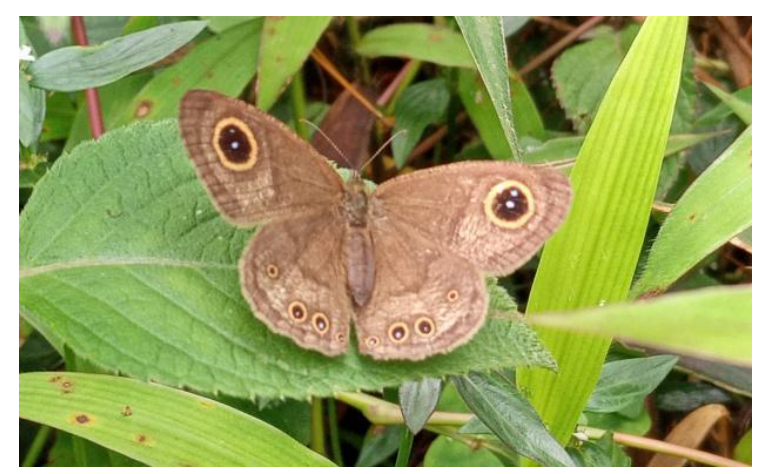

Gambar 1. Yptima baldus

Morfologi Ypthima baldus memiliki sayap atas berwarna coklat muda kekusaman, terdapat cincin ocellus besar sebanyak 3 pasang pada sayap belakang bagian bawah (Akram \& Saghir, 2019). Sayap depan bagian atas terdapat cincin ocellus besar sepasang dengan pinggiran berwarna kuning dan memiliki lima cincin ocelli pada sayap belakangnya (Badrunasar, 2014). Spesies ini memiliki kemampuan terbang berjarak dekat dan rendah diatas tanaman herba, rumput dan semak.

Cagar Alam Gunung Sigogor merupakan habitat yang cocok untuk keberlangsungan hidup kupu-kupu. Hal ini didukung oleh (Sánchez-Bayo \& Wyckhuys, 2019) menyatakan bahwa keberadaan kupu-kupu pada suatu kawasan sangat bergantung dengan dukungan faktor biotik salah satunya ialah ketersediaan vegetasi. Keberadaan kupu-kupu di alam dapat memberikan dampak positif dalam mempertahankan keseimbangan ekosistem dan berperan sebagai indikasi terhadap perubahan lingkungan, sebab kupu-kupu menyukai kawasan yang bersih dan terbebas oleh insektisida (Rohman dkk., 2019). Oleh karena itu kupu-kupu dikategorikan sebagai bioindikator kualitas lingkungan sehingga patut untuk dilestarikan agar selalu tersedia di alam. 


\section{KESIMPULAN DAN SARAN}

\section{Kesimpulan}

Berdasarkan penelitian yang telah dilakukan didapatkan 45 spesies kupu-kupu dari 5 famili. Indeks keanekaragaman pada Kawasan Cagar Alam Gunung Sigogor Kabupaten Ponorogo sebesar $\mathrm{H}^{\prime}=3.1$ yang tergolong dalam keanekaragaman yang tinggi. Nilai Indeks Shannon-wienner tertinggi terletak pada lokasi kelima $\mathrm{H}^{\prime}=3$, sedangkan terendah pada lokasi pertama $H^{\prime}=2.1$. Spesies yang memiliki jumlah individu tertinggi yaitu Ypthima baldus sebanyak 68 indivudu.

\section{Saran}

Penelitian selanjutan diharapkan dapat mencangkup data seluruh kawasan Cagar Alam Gunung Sigogor agar mendapatkan data yang lebih banyak dengan mengembangakan metode penelitian.

\section{DAFTAR RUJUKAN}

Adi, M. B. S., \& Susanti, D. (2017). Keanekaragaman Spesies Kupu-Kupu (Lepidoptera) di Kebun Koleksi Tumbuhan Obat Kalisoro, Tawangmangu. Jurnal Tumbuhan Obat Indonesia, 10(2), 70-77. DOI: https://dx.doi.org10.22435/toi.v10io.6817.7077

Ahmed, S., \& Farid, B. (2018). Diversity of Lepidoptera (Rhopalocera) in natural and modified habitats of Bousaâda, Algeria. World J Environ Biosci, 7(1), 79-83. Retrieved from https://enviromentaljournals.org/issue/volume_7_2018_issue_1

Akram, M, Awan \& Saghir, Hasan. (2019). First Report Of Common Five-Ring Yptima baldus (Insecta: Lepidoptera: Nymphalidae) For Pakistan. Bionotes, 21(3), 5859. Retrieved from http://www.entosocindia.org/bionotes-1.html

Ashari, F. N., Addiniyah, N. R., \& Aini, H. N. (2019). Diversity of Butterflies (Lepidoptera: Rhopalocera) in Sumber Clangap and Waduk Selorejo, East Java. Biota: Biologi dan Pendidikan Biologi, 12(1), 32-37. DOI: http://dx.doi.org/10.20414/jb.v12i1.161

Badrunazar, Anas. (2014). Keanekaragaman Кири-Кири. Banjar: Balai Penelitian Teknologi Agroforestry.

Bahar, I., Atmowidi, T., \& Peggie, D. (2017). Keanekaragaman Kupu-kupu Superfamili Papilionoidea (Lepidoptera) di Kawasan Hutan Pendidikan Gunung Walat Sukabumi, Jawa Barat. Zoo Indonesia, 25(1). DOI: http://dx.doi.org/1052508/zi.v25i.3025

Baskoro, K., Kamaludin, N., \& Irawan, F. 2018. Lepidoptera Semarang Raya. Semarang: Departemen Biologi Universitas Diponegoro. 
Böhm, M. 2018. Troides amphrysus. The IUCN Red List of Threatened Species 2018: e.T160996A867473. http://dx.doi.org/10.2305/IUCN.UK.20181.RTLS.T160996A867473.en. Download on 1 April 2021.

Böhm, M., Chowdhury, S., Khanal, B., Lo, P. \& Monastyrskii, A. 2018. Troides helena. The IUCN Red List of Threatened Species 2018: e.T91188632A118127416. http://dx.doi.org/10.2305/IUCN.UK.20181.RTLS.T91188632A118127416.en. Download on 1 April 2021.

Borror, D.J., C., A. Triplehorn \& Johnson. (2005). Introduction to Study of Insects $7^{\text {th }}$ Edition. C.A, U.S.A: Brooks/Cole, Belmont

Chahyadi, E., Isda, M. N., Destiyana, A., Fitmawati, F., \& Salbiah, D. (2020). Morphology Characterization of Rhopalocera in Two Areas of Resort Bukit Tiga Puluh National Park Riau Province. Jurnal Biodjati, 5(1), 125-137. DOI:

http://dx.doi.org/10.15575/biodjati.v5i.5743

Farzana, Khan, Perveen \& Anzela, Khan. (2017). Introductory Chapter: Lepidoptera. Pakistan: INTECH.

Ilhamdi, M, Liwa., Idrus, Agil, A \& Santoso, D. (2018). KUPU-KUPU Taman Wisata Alam Suranadi. Lombok Barat: Arga Puji Press.

Krebs, C. J. 1989. Ecological Methodology (No. QH541. 15. S72. K74 1999.). New York: NY, Harper\& Row.

Lestari, V. C., Erawan, T. S., Melanie, M., Kasmara, H., \& Hermawan, W. (2018). Keanekaragaman jenis kupu-kupu familia nymphalidae dan pieridae di kawasan Cirengganis dan Padang rumput Cikamal Cagar Alam Pananjung Pangandaran. Agrikultura, 29(1), 1-8. DOI: http://dx.doi.org/10.24198/agrikultura.v29i1.16920

Magurran, A. E. (1988). Ecologycal diversity and its measurement. New Jersey: Pricenton University Press.

[MENLHK]. Kementerian Lingkungan Hidup dan Kehutanan. 2018. Peraturan Menteri Lingkungan Hidup Dan Kehutanan Republik Indonesia No. P 20 Tahun 2018.

Millah, N., Pitaloka, D. A., Ashari, F. N., \& Addiniyyah, N. R.. (2020). Keanekaragaman Kupu-Kupu (Lepidoptera: Rhopalocera) di Kawasan Taman Nasional Bromo Tengger Semeru (TNBTS) Jawa Timur. PROSIDING Seminar Nasional Biologi (SEMABIO) 5. Jurusan Biologi Fakultas Sains dan Teknologi, UIN Sunan Gunung Djati Bandung. Retrieved from http://bio.uinsgd.ac.id/semabio/semabio-2020/

Mogan, Y., Koneri, R., \& Baideng, E. (2018). Keanekaragaman Kupu-kupu (Lepidoptera) di Kampus Universitas Sam Ratulangi, Manado (Diversity of Butterfly (Lepidoptera) in Campus of Sam Ratulangi University, 
Manado). JURNAL BIOS LOGOS, 8(2), 59-68. DOI: https://doi.org/10.35799/jbl.8.2.2018.23357

Mukaromah, A., Husna, I., Lutfiana, K. N., \& Wahyuningsih, R. (2019). Eksplorasi Keanekaragaman Kupu-Kupu (Lepidoptera) dan Status Konservasinya di Taman Nasional Gunung Merbabu Jawa Tengah. Indonesian Journal of Mathematics and Natural Sciences, 42(1), 16-22. Retrieved from https://journal.unnes.ac.id/nju/index.php/JM/article/view/22635

Muller, C.J. \& Tennent, W.J. 2011. Euploea core. The IUCN Red List of Threatened Species 2011:

e.T160339A5362889. https://dx.doi.org/10.2305/IUCN.UK.20112.RLTS.T160339A5362889.en. Downloaded on 28 April 2021.

Muller, C.J. \& Tennent, W.J. 2011. Mycalesis janardana. The IUCN Red List of Threatened Species 2011:

e.T159800A5338328. https://dx.doi.org/10.2305/IUCN.UK.2011-

2.RLTS.T159800A5338328.en. Downloaded on 28 April 2021.

Mustari, AH \& Gunadharma, N. 2016. Kampus Biodiversitas: Kupu-kupu di Wilayah Kampus IPB Dramaga. Bogor: IPB Press.

N N, Win. 2005. External Morphology of Adult Citrus Butterfly, Papilio Memnon (Linnaeus, 1758) and Seasonal Abudance of The Species. Jour. Myan. Acad. Arts \& Sc. 3 (4). Retrieved from https://www.worldcat.org/title/journal-of-themyanmar-academy-of-arts-and-scinece/oclc/54683536

Nino, M. M. (2019). Keanekaragaman Kupu-Kupu (Lepidoptera) di Sekitar Pinggiran Sungai Maslete Kabupaten Timor Tengah Utara. BIO-EDU: Jurnal Pendidikan Biologi, 4(2), 50-58. DOI: https://doi.org/10.32938/jbe.v412.386

Payra, A. 2020. A note on the defence by Eurema blanda Boisduval (Lepidoptera: Pieridae) Pupae in response to oviposition behaviour of the chalcid wasp Brachymeria sp.(Hymenoptera: Chalcididae). Revista Chilena de Entomologia. 46(3), 485-487. DOI: https://doi.org/10.35249/rche.46.3.20.13

Peggie, D. (2014). Diversitas dan Pentingnya Kupu-Kupu Nusa Kambangan (Jawa, Indonesia). Zoo Indonesia, 23(1). DOI: http://dx.doi.org/10.52508/zi.v23i1.370

Priyono, B., \& Abdullah, M. (2013). Keanekaragaman jenis kupu-kupu di Taman Kehati UNNES. Biosaintifika: Journal of Biology \& Biology Education, 5(2), 100-105. DOI: https://dx.doi.org/10.15294/biosaintifika.v5i2.2749

Rahayuningsih, M., Oqtafiana, R., \& Priyono, B. (2012). Keanekaragaman Jenis KupuKupu Superfamili Papilionoidae di Dukuh Banyuwindu Desa Limbangan Kecamatan Limbangan Kabupaten Kendal. Jurnal Mipa, 35(1). Retrieved from https://journal.unnes.ac.id/nju/index.php/JM/article/view/2092

Rahman, A., Wulandari, M., \& Yusniar. 2018. Identifikasi Jenis Kupu-Kupu (Lepidoptera) di Kawasan Deudap Pulo Aceh Kabupaten Aceh Besar. Prosiding 
Biotik, 6(1). $\quad$ Retrieved from https://www.jurnal.arraniry.ac.id/index.php/PBiotik/article/view.4082

Rohman, F., Efendi, MA \& Andriani, LR. (2019). Bioekologi Кири-kuрu. Universitas Negeri Malang, Malang.

Rusman, R., Atmowidi, T ., \& Peggie D. (2016). Butterflies (Lepidoptera: Papilionoidea) of Mount Sago, West Sumatra: Diversity and Flower Preference. HAYATI Journal of Biosciences. 23, 132-137. DOI: http://dx.doi.org/10.10.16/j.hjb.2016.12.001

Safe'i, R., Erly, H., Wulandari, C., \& Kaskoyo, H. (2018). Analisis keanekaragaman jenis pohon sebagai salah satu indikator kesehatan hutan konservasi. PERENNIAL, 14(2), 32-36. DOI: https://doi.org/10.24259/.v14i2.5195.

Sánchez-Bayo, F., \& Wyckhuys, K. A. (2019). Worldwide decline of the entomofauna: A review of its drivers. Biological conservation, 232, 8-27. DOI: https://doi.org/10.1016/j.biocon.2019.01.020.

Sari, R. P., Mawarni, E. D., Nurlatifah, A., Ulinnuha, R., Sari, E. K. A. P., Annisa'Rahmatul, F. I. T. R. I., \& Irawanto, R. (2019). The diversity of butterflies (Insecta: Lepidoptera) in Purwodadi Botanical Garden, Pasuruan, East Java, Indonesia. In Prosiding Seminar Nasional Masyarakat Biodiversitas Indonesia (Vol. 5, No. 2, pp. 172-178). DOI: https://doi.org/10.13057/psnmbi/m050205

Setiawan, Rendy., Retno Wimbaningrum, dan Siti Fatimah. (2018). Keanekaragaman Jenis Kupu-Kupu (Lepidoptera:Rhopalocera) di Zona Rehabilitasi Blok Curah Malang Resort Wonoasri Taman Nasional Meru Betiri. Natural Science: Journal Of Science And Technology. 7 (2), 252 - 258. Retrieved from https://jurnal.untand.ac.id/jurnal/index.php/ejurnalfmipa/issue/view/1445

UNEP-WCMC (Comps.) 2020. Checklist of CITES species - CITES Identif ication Manual. CITES Secretariat, Genev a, Switzerland, and UNEPWCMC, Cambridge, United Kingdom. Accessed on 08/08/2021. https://checklist.cites.org/\#/en 